\title{
Współczesne znaczenia wody i zieleni w biurowcu wizytówce - na przykładzie Business Tower Norymberga
}

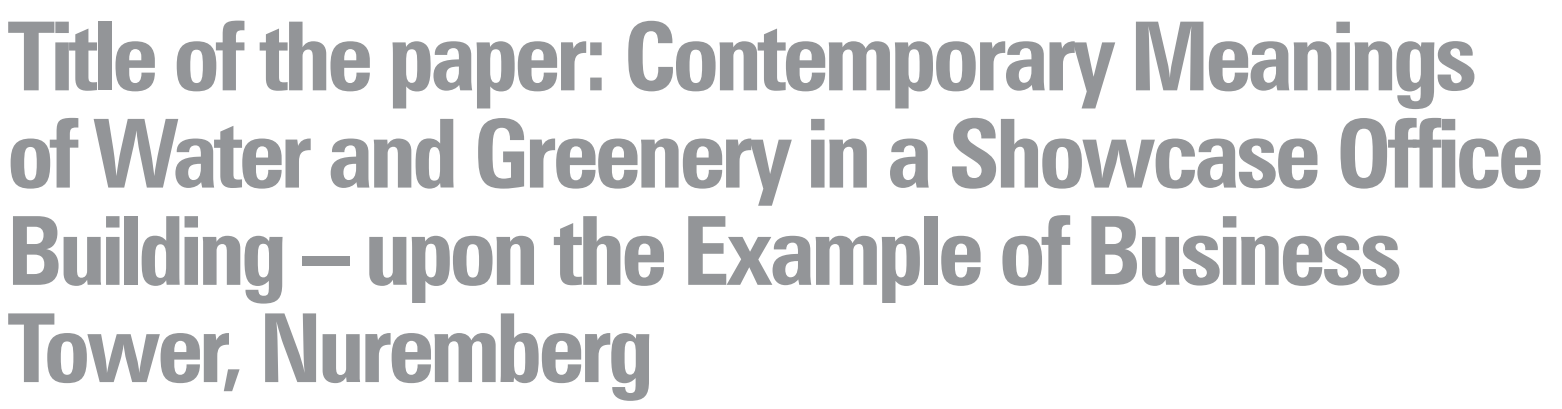

\begin{abstract}
Abstrakt
Norymberga - drugie po Monachium miasto Bawarii - jest lokalizacją również drugiego co do wysokości budynku biurowego tego landu - Business Tower Nürnberg. Obiekt ten jest zarazem główną siedzibą towarzystwa ubezpieczeniowego, jak i stanowi współczesną wizytówkę miasta. Na prezentowany kompleks biurowy składa się cylindryczna wieża oraz siedmiopiętrowy blok obwodowy w kształcie czworoboku, na którego dziedzińcu wewnętrznym znajduje się spektakularny basen wodny oraz przestrzeń do rekreacji wśród zieleni. W artykule autor podejmuje próbę określenia współczesnych znaczeń wprowadzenia atrakcyjnej zielonej przestrzeni rekreacji do biurowego kompleksu o charakterze reprezentacyjnym zarówno dla firmy, jak i dla miasta. Autor zwraca uwagę na wielość znaczeń i złożoność wartości, często nieoczywistych, wynikających z tworzenia obiektów typu wizytówka dla szeregu różnorodnych odbiorców.
\end{abstract}

\begin{abstract}
Nuremberg - the second biggest city in Bavaria, after Munich - is also the location of the second tallest building in this state Building Tower Nürnberg. This building is the main seat of an insurance company, as well as a contemporary showcase of the city. The entire office complex in question consists of a cylindrical tower and a peripheral seven-floor building in the shape of a quadrangle, in the internal courtyard of which there is a spectacular water pool and a space for recreation amongst abundant greenery. In this paper the Author makes an attempt at determining contemporary meanings relating to the introduction of an attractive recreational green area in the office building of a representational character for the company itself, as well as for the entire city. The Author points to the multitude of meanings and the complexity of values, often quite unobvious ones, resulting from the creation of showcase buildings for a number of diversified recipients.
\end{abstract}

Słowa kluczowe: biurowiec, przestrzeń rekreacji, zieleń i woda, wizytówka miasta, wizytówka firmy Keywords: office building, recreational space, greenery and water, city showcase, company showcase

\section{Wizytówka miasta}

Współczesna moda na wyszukane projekty zieleni wokół biurowców, które mają na celu promocję obiektów i firm znalazła również swój wyraz w Norymbergi. Jest nim kompleks biurowy firmy Nürnberger Versicherung z przykuwającą uwagę wieżą, zwaną Business Tower Norymberga - będąca nowoczesną wizytówką starej, bo z ponad stuletnią tradycją firmy. Wieża stanowi także wartość dla miasta. Będąc dominantą architektoniczną, jest jednym z punktów orientacyjnych, tarasem widokowym oraz nowoczesnym symbolem miasta. Firma jest historycznie związana z Norymbergą, jest sponsorem słynnego na całym świecie bożonarodzeniowego jarmarku (Christkindlesmarkt), wspiera także noce kultu-

\section{Showcase of the city}

The contemporary fashion for sophisticated greenery projects around office buildings aimed to promote the buildings and companies has also found its expression in Nuremberg. It is an office complex of Nürnberger Versicherung, with an eye-catching tower, called Business Tower Nürnberger, which is a state-of-the-art showcase of this old company, boasting an over one hundred years' tradition. The tower constitutes an asset of the city itself, too. As an architectural dominant, it is one of the city's landmarks, a vantage point, and a modern symbol of the city. The company, historically associated with Nuremberg, is a sponsor of the local world famous Christmas market (Christkindlesmarkt); furthermore, it supports 
ry, pokazy koni i mistrzostwa piłkarskie organizowane $w$ tym mieście.

Norymberga kojarzona jest głównie z procesami norymberskimi po II Wojnie Swiatowej, zabytkową architektura i tradycyjnymi wyrobami sprzedawanymi na świątecznym jarmarku. Współczesne oblicze miasta jest mało popularne, a mieszkańcy narzekają na brak atrakcyjnych przestrzeni zielonych. Tak też za wyjątkiem kilku urokliwych zakątków, w kontekście całego miasta, mało jest zaplanowanych przestrzeni rekreaci, a obecnosć rzeki tym ketem. Oczywiśc ja sie wskaźc kilka rana pod tym ka odbicgajacych ods tak da wa wskazac kilka re do nich panki odzyodnicze, w tym pięhny ogrod zoologiczny. Mozie jedok whas wie dim ger zdecydowala się wyrónic swoj obiekt nie tylko za pomoca wysokosci, ale także wprowadzając atrakcyjna przestrzeń rekreacji oferującą zarówno dostęp do wody,
jak i zieleni.

\section{Wizytówka firm}

Wieża Business Tower Nürnberg (BTN) urozmaica panoramę miasta Norymberga od 2000 roku. Jest częścia większego kompleksu biurowego i główną siedzibą znamienitego towarzystwa ubezpieczeniowego Nürnberger. Kompleks składa się z obwodowo usytuowanych budynków, które zamykają przestrzeń wnętrza założenia z czterech stron. Wszystkie budynki utrzymane sa w stonowanej kolorystyce stali i szkła, a elewacje maja typowo biurowy charakter podziału płaszczyzny okien. Zachodni narożnik - od strony starego miasta - akcentuje wspomniana wieża oraz znajdujący się przed nia plac $\mathrm{z}$ fontanna. $Z$ kolei możliwość wglądu w przestrzen dziedzińca osobom postronnym daje północny narożnik kwartału, który jest ażurowy na poziomie parteru i pierwszej kondygnacil. Przed fasadmi od zachodu pojawiaja

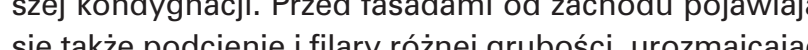
się takíe podcienie fym samym pierzeje od strony ulicy Ostendstraße. Ela wacja frontowa przyozdobiona została sporych rozmiarów logiem.

Wewnątrz tak stworzonego kwartału, niejako w atrium znajduje sie misternie zaplanowana przestrzeń rekreaznajduje się misternie zaplanowana przestrzen rekreacyjna. Zapewia ona pracownkom biurowca kontak $z$ woda $-w$ formie jeziora uformowanego przy krawędziach budynków oraz z zielenią skupioną na wyspie połączonej kladkami z wejsciami i placykiem wewnętrznym (będącym kontynuacją zewnętrznego placu z fontanną). Całość przestrzeni rekreacyjnej opiera sie na geometrycznej koncepcji wydzielania miejsc: tych z wodą i z zielenią, przy których można usiąść oraz tych spacerowych podkreślonych w posadzce. Tak też powierzchnia terenu, obok części zielonych, podzielona została materiałami na kamienną, drewnianą, brukowaną i betonową. Zielen w omawianym załozeniu tworzą rośliny oddziałujące w rożnej skali, zarówno trzciny, trawy i kwiaty (irysy) jak i krzewy oraz drzewa. Kompozycje uzupełniają stalowe detale mocowań, balustrady i ławki. cultural nights, horse shows, and football championships organised in this city.

Nuremberg is predominangly associated with the Nuremberg Trials after the World War II, historical architecture, and traditional goods sold at the Chrismas market. The contemporary side of the city is not particularly popular, and its inhabitants complai about the scarcity of attractive green spaces. Besides several quite charming nooks, in the context of the entire city there is very little recreational space, and the presence of the Pegnitz river and numerous little lakes is rather poorly used in this respect. Naturally, there are some projects which can be emphasised as completely different from this diagnosis, such as in the parks, with a beautiful zoological park being pany of Nürnerger decided to make its elfice stand pant, not ducing attractive recreationa space, offering access to water as well as to greenery..

\section{Showcase of the company}

Business Tower Nürnberg (BTN) has diversified the panorama of Nuremberg since 2000. It is a part of a bigger office complex and the main seat of a renowned insurance company, Nürnberger. The comwhich close the space of the interior of the entire project from four sides. All the buildings are maintained in subdued colours of steel and glass, and their façades have a typically office-like character of the division of the window plane. The western corner, facing the old town, is emphasised with the aforementioned tower and a square with a fountain located in front of it. The space of the courtyard, on the other hand can be viewed by outsiders through the northern corner of the block, which is of an openwork character at the level of the ground and the first floor. In front of the façades from the west there also appear arcades and pillars of different widths, diversifying the frontage facing Ostendstraße. The front façade is ornamented with a logo of a considerable size

Inside a block created this way, as if in the atrium, there is an intricately designed recreational space. It provides people working in the office building with contact with water, which assumes the form of a lake the greenery accumulated on an island linked with the entrances and the inner piazza (a continution of the external square with the fountain) by means of footbridges. The entire recreational space is based on a geometrical concept of demarcating places with water and greenery, offering seats to rest for a whil or walking lanes emphasised in the pavement. And thus, besides the green parts, the entire arement. And divided by individual materials into a stone, wooden cobbled, and concrete one. The greenery in this project is constituted by plants interacting in differen scales: reeds, grasses, and flowers (irises), as well as shrubs and trees. The composition is completed by steel details of fixtures, balustrades, and benches. In
Jak nakazują współczesne trendy, wszystko to możliwe jest też do zobaczenia $w$ Internecie, za pomocą wirtualnego spaceru'

Historia omawianego obiektu zaczęła się w październiku 1992 roku, kiedy ogłoszony został konkurs architektoniczny na główną siedzibe jednego z najwiekkszyc niemieckich towarzystw ubezpieczeniowych, działajace go na rynku od 1884 roku i mającego obecnie ponad 4 miliony klientów. Oczekiwania były duże. Obiekt mia manniać $100000 \mathrm{~m}^{2}$ powierzhni biurowej $(4,5$ tyiąca miejsc pracy), stotó po firmow drukej 44,5 tysiąca 作, liczne sale king (na tysiąc miejsc postojowych) oraz przestronny king (na ty

zziedziniec.

marcu 1993 roku jury z ponad 110 nadesłanych projektów wyłoniło zwycięzcę. Pierwszą nagrodę otrzymall architekci Peter Durschinger i Friedrich Biefang z Am merndorfu, ktorych projekt wyrónial się wysoką jakos cią, zarówno $w$ warstwie architektonicznej jak $\mathrm{i}$ urban stycznej.

Projektanci dobrze odczytali potrzebę inwestora, która polegała nie tylko na zaproponowaniu przestrzen realizującej oczekiwany program funkcjonalny, ale także konieczności utożsamienia wartości firmy z jakościa przyjętych rozwiązan, zarowno koncepcyjnych, jak i konstrukcyjnych. Wazna byla wysokosc, ale tez solidnosć. BTN stoi na skale z piaskowca. Dzięki kombinowanej konstrukcji fundamentowej - 52 betonowym palom o średnicy do 1,30 m i maksymalnej długości $22 \mathrm{~m}$ oraz płycie o grubości 1,50 $\mathrm{m}$ - całkowita waga wieży mogła wynosić prawie 50000 ton. Zadbano także o wytrzymatość wieży na obciążenie wiatrem, gdyż wpływa to $\mathrm{n}$ komfort pracy i nośność budynku. Kolumny wsporcze których średnica zwęża sie ku górze (od 90 do $30 \mathrm{~cm}$ ) wraz z obszarem rdzenia budynku - przenosza gtówne obciazenia. W wyliczeniach bazowano na danyiemiekiej stuzby meteorogicznej i wymiarach komponentów budowlanych. Zminimalizowano drompontow budowy. Zastosowno najnowoczéniejze odchylenie wieży. Zastosowano najnowoczesniejsze śch scian rdzeniowych zastosowano nowy system montazu

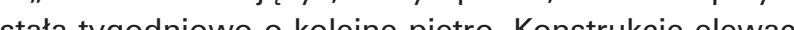
możn by postać bez skemplikowa nejo zewacj moża bylo posta wic bez skompllkowanego zewnętrnego rusztownia. Fasada BTN ma podwojną powtoke składającą się z elementów (szer. 2,30 m i dł. 3,40 m) kto byly na bleżaco dostarczane na budowe, a następnie szybko montowane. Było to możliwe dzięki konsolom ułatwiającym zawieszanie elementów na budynku, a później sprawne łączenie ich ze sobą.

Zadbano również o rozwiązania ekologiczne i efektywne utrzymanie budynku. Mimo wysokości budynk dwuwarstwowa fasada przez wiele miesięcy w roku zapewnia "naturalną wentylację" poprzez okna. Kurtyna przeciwsłoneczna za zewnętrzną powłoką fasady pozostaje w pełni skuteczna nawet $w$ wietrzne dni i na dużych wysokościach. Szczelina fasady może być napowietrza- line with the contemporary trends, all this can be also seen on the Internet, taking a virtual stroll.

The history of this structure began in October 1992 when an architectural competition for the main seat of one of the biggest German insurance company, operating since 1884 and boasting over 4 million customers, was announced. Expectations were huge. The building was to house $100,000 \mathrm{~m}^{2}$ of office space $(4.5$ thousand workstations), a company canteen, a printing house, numerous conference halls, a warehouse for all materials, an underground car park (for one thousand parking spaces), and a spacious courtyard. Me Pubmitted designs. The first prize went to architects Peter Durschinger and Friodich Blefang from Anquality, both in the architectural and urbas to its top The designers interpreted the investor's need ver well-it consisted not only in proposing a spaed very would fulfil the expected functional programme, but also in identifying the values of the company with the quality of the solutions adopted, both the conceptual and the structural ones. The height was important but then so was the robustness of the edifice. BTN sits on sandstone. Thanks to a combined foundation structure -52 concrete stilts with the diameter up to 1.30 $\mathrm{m}$ and the maximum length of $22 \mathrm{~m}$, and a 1.50-thick slab - the total weight of the tower could reach nearly 50,000 tons. The resistance of the tower against the wind load was also taken care of, as it has its effect on the working comfort and the bearing capacity of the building. The supporting columns, whose diameter narrows upwards (from 90 to $30 \mathrm{~cm}$ ) along with the area of the core of the building bear the main load. The calculations were based on the data provided by the German meteorological services and the dimensions of the building components. Vibrations and the deviation of the tower were minimised. State-of-theart technologies were applied. For the first time in Gemany, a new "self-suspending" assembly system was applied in the core walls, which made the tower grow one floor every week. The structure of the elevation could be erected without any complicated externa scaffolding. The façade of BTN has a double skin, consisting of elements $(2.30 \mathrm{~m}$ - wide and $3.40 \mathrm{~m}$ - long which were delvered to chlo cild ing them with each other.

ffective maintenance of the height of the edifice, the double-skin facade secured the "natural ventilation" through the windows for many months in the year. The solar protections for behind the outer skin of the façade remains fully effective even on windy days and on big altitudes. The façade gap can be aerated aerodynamically and accessible for the purposes of maintenance and cleaning. A cleaning gondola secures safe external cleaning. Thanks to such a natural way of operation of the 
Karolina Sobczyńska przypomina, że architekt korzysta jektując przestrzeń miejską, nadając jej ksztatt, wpływa na zachowania społeczne jej u̇̇ytkowników, na organizacje życia społecznego i poczucie tożsamości. Kształt środowiska wpływa znacząco na zmysty i psychike człowieka."당 jest to jednak wpływ jednoznaczny i determinujaccy stosunki miedzy ludzkie w przestrzeni. Jedynie wpływ o charakterze inicjujacym, stwarzajacym cztowiekowi nowe mozliwości Jan Gehl przypomina: fizyczne otoczenie nie wptywa bezpośrednio na "Jkośc fizyczne otoczenio nie wolywa bezpośrednio na jakośc ocznych, architekci i urbanisci moga miec wplyw na mozilwosc spotykania, przygladan ipzysuchwania sié ludziom - moziliwośc. knoca sama w sobie jest wartosciar, a zarazem nabler znaczenia jako podstawa oraz punkt wyscia dla innych form kontaku. "Kontynuając te mysl: "Zycie między budynkami oferuje okazje do przebywania z innym w sposob lużny i niewymagający. (...) Nawet wygladanie przez okno od czasu do czasu, o ille ma sie clekawy widok, może przynieść korzyści. Bycie wśród innych, widzenie ich i słyszenie, odbieranie bodźców, prowadzi do pozytywnych doświadczeń jako alternatywy dla bycia samemu. Niekoniecznie jest się z konkretna osoba, jednak jest się z innymi. (...) Kontakt o niskiej intensywności to sytuacja, z ktorej mogą wynikac inne formy kontaktu. (...) Moziliwość spotykania sąsiadów i wspótpracowników, często w związku z codziennym przemieszczaniem się, stwarza nieocenioną okazję do nawiązywania i późniejszego podtrzymywania znajomości w sposób luźny i niewymagający." ${ }^{18}$

Marketingowe podejście do kreowania wizerunku Współcześnie dla firm, tak jak do tej pory jakość świadczonych usług tak też właściwy wizerunek staje sie gównym elementem budowania pozycii na rynk Sktada sie na to wiele czynników, miedzy innymi konio.sność szybkiego i skutecznego przycian tów, czyli tych którzy moga oraz chca skorzystać z oferowanych przez firme uslug. Jednak rowniez z potrzeby zych praco on nych pracow. Tow, kirzy będą chcieli zwązac się z fir-

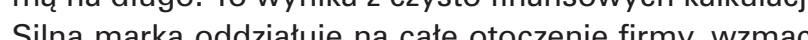

il. 5. Stalowe detale dziedzińca / steel details of the courtyard
il. 6 . Widok na jezioro wewnetritrne / view of the inner lake
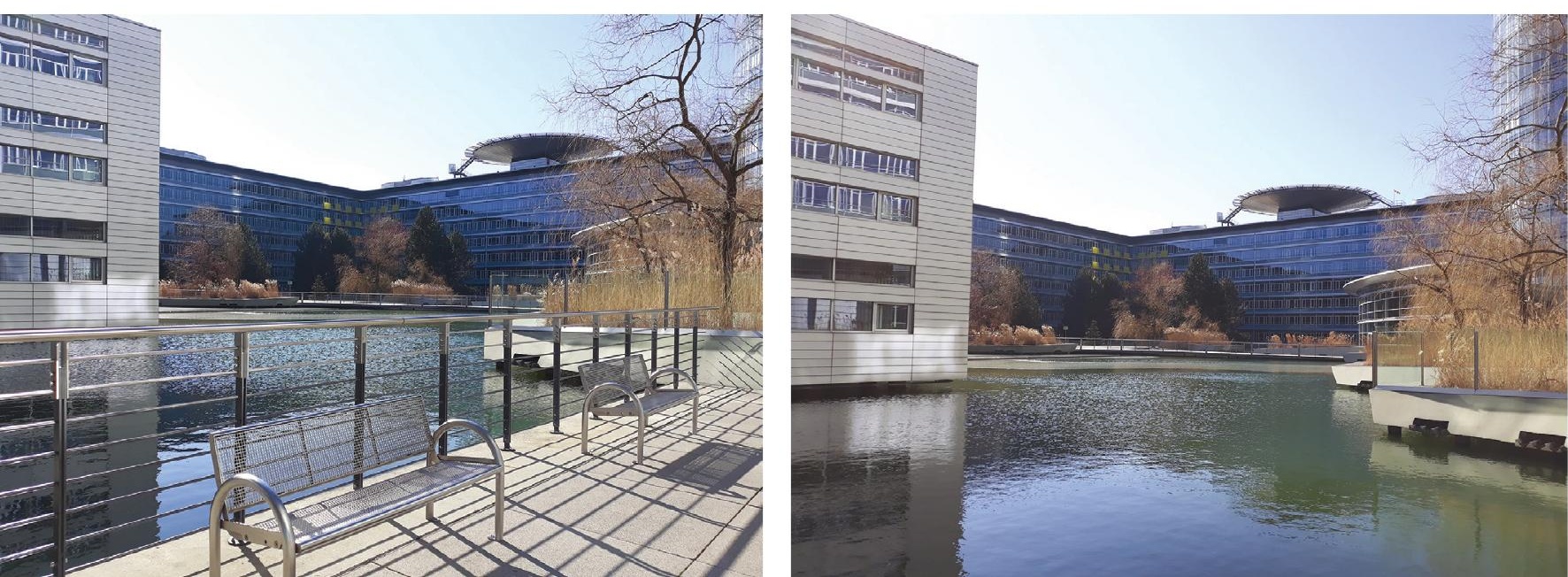

niając zaufanie klientów, inwestorów i udziałowców. Na ketingowych, w tym też, co nas interesuje - odpowiedn wybór lokalizacji siedziby firmy i estetyka tejże budow oraz wszystkie jej cechy. Firmy zaczynają dostrzegac że wybór siedziby może świadczyć o prestiżu przedsiebiorstwa i dostarczać korzyści wizerunkowych. Odbió miejsca i wartości z nim związanych przekłada się na po strzeganie firmy w oczach kontrahentów i potencjalnych strzeganie

Na decyzie o siedzibie składa się wybór miasta, cena wy.

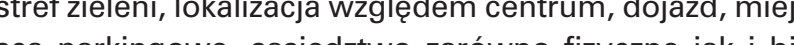
sca parkingowe, sąsiedztwo zarowno fizyczne jak i bije sasedzwo biznesowe, popzez prypack jej sas i dzwo biznowe, popzez prypadowe nawe spokania, wzajemie na siebie oddziajue. Pracodawey, jak i pracownicy róznych firm mogą się sobą inspirowac. Nie bez znaczenia dla budowy silnego wizerunku firmy jest także aspekt ochrony srodowiska. Ma to potwier dzenie w słowach Jamesa Wines, ktory rozważając postrzeganie budowli jako trwalej pisal, ze: „Zasadniczym warunkiem długowiecznosci budowli jest połączenie natury i sztuki. Za warte zachowania uznaje się te sposród budowli, które są zarówno piękne, jak i przyjazn srodowisku." Mozna zauwazyc, ze firmy, ktore w swoich strategiach uwzględniają działania proekologiczne, nie ulokują swojej siedziby w biurowcu, ktorego technologia budowlana odbiega od ich filozofii działania. Widać to również na omawianym przykładzie, gdzie aspekty wydajności i odpowiedniej certyfikacji budynku odgrywają bardzo dużą rolę. Ekologia jest zatem ważna nie tylko dla miasta i jego mieszkańców, ale też dla firm Nürnberger Versicherung.

$Z$ kolei dziedzina z pogranicza HR i marketingu jaka jest employer branding, a szczególnie tzw. zewnetrzny je ployer branding docenia wartość wizerunku siedziby firmy dla pracownik. Chodzi o rzyciagniecie i utzyma ie najepszych pracowników, poprzez zapewnienie nie napszych pracown kow, poprzz zapew ienle im śl wyikaj sci wy jik ja zo zre

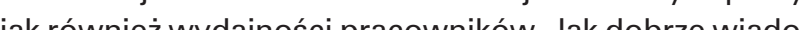

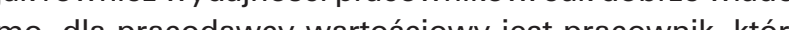
mo, dla pracodawcy wartosciowy jest pracownik, który przywiązany jest do firmy, ceni sobie mozliwośc bycia jej częscią, identyfikuje się z nią i chce działac na jej rzecz. Zadowolenie i zaangażowanie obecnych pracowników firmy jest też uwiarygodnieniem i elementem wzmacniającym skuteczność oficjalnych działań komunikacyjnych $w$ ramach employer brandingu.

Inwestycja w pracownika, w tym w jego miejsce pracy, wyplywa z finansowego interesu pracodawcy. Spójne, przemyslane, wiarygodne dzialania wizerunkowe przyciągają do organizacji talenty i przekładają się na zmnieszenie rotacji pracowników oraz optymalizacje kosztów rekrutacji. Oprócz wynagrodzenia firmy oferuja karnety na siłownię, udział w szkoleniach, firmowe telefony, lap-
Companies start to notice that the choice of their main be a source of image-related benefits. The reception of the place and values connected with it translate into the way the company is perceived by its contractors and potential customers. The decision concerning the main seat of the company is multifaceted: the choice of the city, the lease rate, the appearance of the building, the presence of recreational spaces, green zones, its location towards the city centre, access, parking spaces, its physical and business environment. The surroundings in which the company develops and its business environment interact with each other, even through quite accidental meetings. Employers as well as employe

Another aspect which is also significant for building Antrong ime of the company is the element of vironmental protection. It finds its confirmation of enwords of James Wines, who wrote while deliberat ing on the perception of a building as a permanent feature, "The principal condition for longevity of the building is a combination of nature and arts. Buildings which are both beautiful and environmentally friendly are recognised as worth preserving." ${ }^{\prime \prime} \mathrm{It}$ is observable that companies which include pro-ecoobservable that companies which include pro-ecomain seats in an office building the constructiona technology of which deviates from their philosophy. It is also visible in the example discussed herein, where the aspects of efficiency and appropriate certification of the building play a crucial role. Hence, ecology is important not only for the city and its inhabitants, but for Nürnberger Versicherung, too.

On the other hand, the field of study in between HR and marketing, which is employer branding, and particularly the so-called external employer branding appreciates the value of the image of the company's seat for the employee. It is about attracting and keeping the best employees, by providing them with a comfortable working space and additional benefits resulting from a good location and an attractive receational space. It is important for a nice atmosphere at work, as well as for the efficiency of employees. As it is commonly known, employers value employees who are attached to the company, who appreciit and wish to work for its benefit Satisfaction with

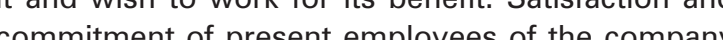
is also a confirmtion and a way of strengthening of (1) within the scheme of employer branding.

investing in an employee including the employee's workplace, stems from the financial interest of the employer. Coherent, well-considered, reliable imagebuilding activities attract true talents to the organisation and translate into the reduction of rotation of workers and optimisation of the recruitment costs. Besides remuneration, companies offer gym tickets, participation in trainings, company phones, laptops, and cars. Building the image of a good employer is also associated with securing benefits making the 
topy i auta. Budowa wizerunku dobrego pracodawcy ${ }^{10}$ wiąże się także z zapewnieniem korzyści wyróżniających firmę od konkurencji. Na przykład z wykorzystywaniem nowoczesnych kanałów komunikacyjnych i technologii ma właśnie jedną z największych sieci LON w Europie ${ }^{12}$ Składa sie to bowiem na postrzeganie pracodawcy jako atrakcyjniejszego.

\section{Budowle wizytówki dają korzyści różnym odbiorcom} Ba sie zaumażć, ż abiektom typu kompleks bicom Number versicherung sawione sa rowniez dodatkowe cele wiażce sie z pryy ub mistu w ki miejscu

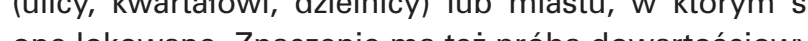
one lokowne. Znaczenie ma tez próba dowartosciowywania samego miejsca pracy - fimy, a postednio i pracownika. Co z kolei w konsekwencji przyczynia się do tworzenia godnego srodowiska pracy. Kluczowym zabiegiem okazuje się wprowadzanie przestrzeni rekreacjl, sankcjonując potrzebę wytchnienia, co jest niewątpliw korzyścią dla pracownika. Jednak także nadawanie przestrzeni rekreacji wysokiego standardu jakościowego, wprowadzanie atrakcyjnie rozplanowanej zieleni i wody stanowi korzyść wizerunkową dla firmy i miasta z jego mieszkancami. Warto zwrócić uwagę tutaj na znaczenie społeczno-przestrzenne w szerszej skali danego miejsca. Ta nowa przestrzeń rekreacji umożliwia interakcje z sąsiedztwem. Kompleks biurowy Nürnberger poprzez otwarcie narożnika kwartału i niejako zaproszenie mieszkańców do środka jest przykładem architektury właśnie tak kształtowanej. Przestrzeń dziedzińca jest bowiem dostępna zarówno dla pracowników, klientów przestrzeni biurowych, ale także osób chcạcych jedynie pobyc w przyjaznym miejscu umożliwiającym rekreacie. Zie leń wykorzystana została jako narzedzie uatrakcy.jiania i podwyższania jakóci przestrzeni miejskiej, w której zlokalizowany został obiekt.

\section{PRZYPISY}

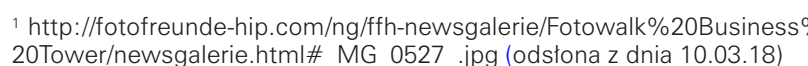

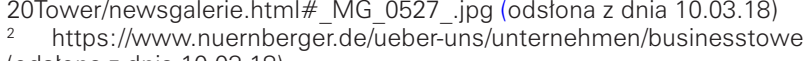
(odstona $z$ dnia 10.0 .0 .18 .
3 h http:/livecam 10.03.18

$4 \mathrm{https}: / /$ Www.world-architects.com/is/adle-and-olesch-landschaftsarch-
tekten-und-stadtplaner-nurnberg/project/nurnberger-versicherung-haup-

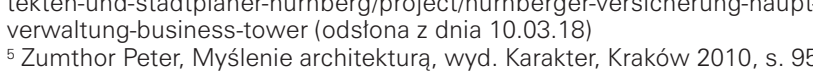
6 Sobczýńska Karolina, Zielén jako element wspótczesnego miasta i je
rola w przzestrzeniach publicznych Poznania, Praca doktorska obroniona na Wydziale Architektury Politechniki Poznańskiej, Poznań 2014, s. 32

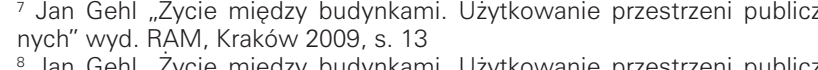
8 Jan Geht. .Zycie miedzy budynkami. Uìytkowanie przestrzeni publicz-
nych" wyd. RAM, Kraków 2009, s.18-19

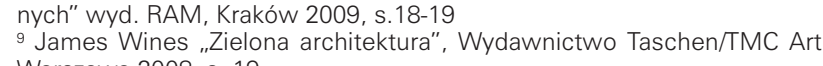
Warszawa 2008, s. 19

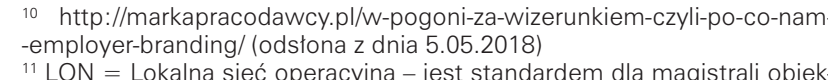

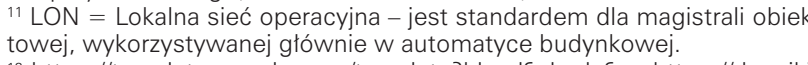

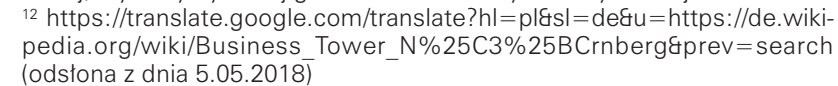

company stand out among its competition, for ex ample, with making use channels and such technologies as LON". The office complex at 100 Ostendstraße has one of the biggest LON networks in Europe' ${ }^{12}$, as it contributes to the employer being perceived as attractive.

\section{Showcase buildings offer benefits to different}

recipients

It can be observed that such facilities as the Nürnberger Versicherung office complex have to fulfil additiona goals, associated with providing additional values to their location (street, block, district) or the city where they are located. What is also important is an attempt to appreciate the very workplace - the company, and indirectly also the employee, which in turn contributes to the creation of a decent work environment. It turns out that the key measure is to introduce recreatio into the space, legitimising the need of respite, whic undoubtedly is to employees' benefit. Nevertheless, providing the recreational space with a high quality standard, introduction of attractively arranged greenery and water constitutes an image-building benefit for the company and the city with its inhabitants. is worth pointing out to the social and spatial significance of a particular location in a broader scale. This new recreational space facilitates interactions with the neighbourhood. The Nurnberger office complex thanks to the opening of the corner of the block and as inviting city residents in, is an example of architecthe designed his way. The space of the courtyard is acessible the spend some time in a friendy space fostering retoxtion. Greenery has been used as a tool of improving (he atractiveness and au which the building is situated.

ENDNOTES

1 hittp://fotoffreunde-hip.com/ng/ffhh-newsgalerie//Fotowalk\%20Bu-
siness\%20Tower/newsgalerie.html/t__MG_0527_.jpg (access on siness $\% 200$
10.03 .18

https://Www.nuernberger.de/ueber-uns//unternehmen/busines
stower/ (access on 10.03.18)

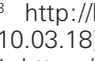

https://Mww.world-architects.com/is/adler-and-olesch-landschaffsarchitekten-und-stadtplaner-nurnberg/project/nurnberger-versi-
cherung-haupteverwaltung-business-tower (access on 10.0 .03 . 18 )
5 Zumthor Peter, Myślenie architektura, Karakter Publishing House, Cracow 2010, p. 95
sobczýnska Karolina, Zieleń jako element wspótczesnego miast i Sobczynska Karolina, Zielen jako element wspotczesnego miasta
i jej rola w przestrzeniach publicrnych Ponzania Greenery as an
Element of the Contemporary City and Its Role in Public Spaces of Poznanh', Ph.D. dissertation defended at the Faculty of Architecture. Pornań University of Technology, Poznañ 2014, p. 32

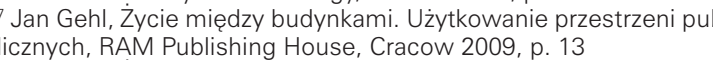
- Jan Gehl, Zycie mieddzy budynkami. Użytkowanie przestrzeni publicznych, RAM Publishing House, Cracow 2009, pp. 18-19
vames Wines, Zielona architektura, Taschen/TMC Art. Publishing House, Warsaw 2008, p. 19
10 htpp:/markapracodawc

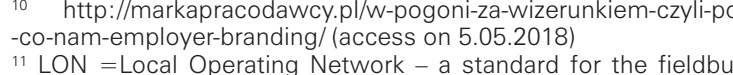
ssed predominantly in the automatic control of buildings.

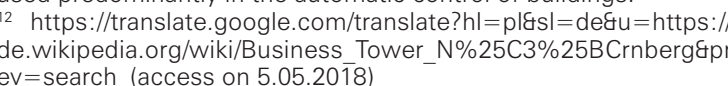

LITERATURA

1] Gehl J. Życie mieddzy budynkami. Uzitkowanie przestrzeni publicz[2] Wines J. Zielona architektura, Wydawnictwo Taschen TMC Ant

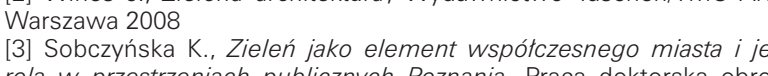
iona na Wydziale Architektury Politechniki Poznańskiej, Poznań 2014

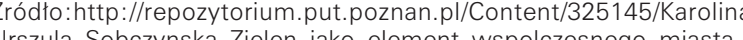

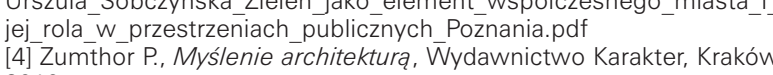
2010 (4) Zumthö P., Myślenie architektura, Wydawnictwo Karakter, Kraków [5] https://Www.world-architects.com/is/adler-and-olesch-landschafts-
-architekten-und-stadtplaner-nurnberg/project//urnberger-versiche rung-hauptverwaltung-business-tower (odstona z dnia 10.03.18)
[6] https:/Wwww architekten-und-stadt [1] planer-nurnberg/project/neue-messe-stutt-
gart-1 (odstona z dnia 10.03.18) [7] https://www.world-architects.com/is/adler-and-olesch-landschaftsarchitekten-und-stadtplaner-nurnberg/project/tiergarten-nurnberg-del-
phinlagune-und-manatihaus (odstona z dnia 10.03.18) phinlagune-und-manatihaus (odstona 2 dnia 10.03 .18$)$
[8] http://www.alpha-ic.com/en/references/nordostpark-nuremberg.

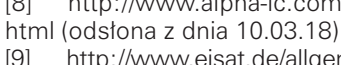

19] httr:://Www.eisat.de/allgemein/the-ivg-future-base-burogebaude-

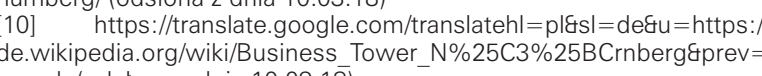
search (odstona $z$ dnia 10.03 .18
[11] http://fotofreunde-hip com

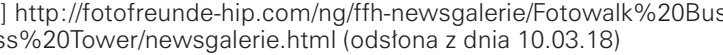

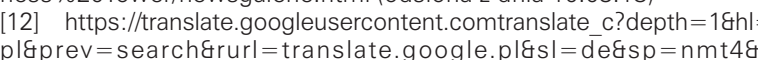

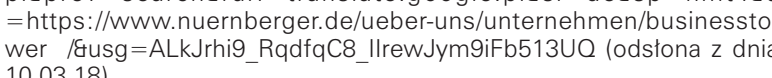

[13] hitp

10.03.18) / ka-ogrodowa-77777/zielelen-w-ekologicznym-projektowaniu-buddynkow-ich-otoczenia-15889 (odstona z dnia 10.03.18)
[15] http://markapracodawcy.pl/w-pogoni-za-wizerunkiem-czyli-po-co-

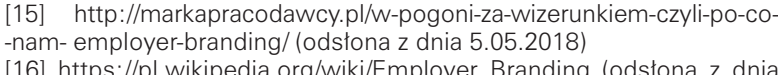
[16] https:///pl.wikipedia.org/wiki/Employer_Branding (odstona z dnia
5.05 .2018 ) 17] http

(t)

[18] https://wizualni.p//employer-branding-rola-budowaniu-wizerunku

-firmy/ ${ }^{19}$ https://www.wprost.pl/407987/O-wizerunku-firmy-w-duze-mie [ze-swiadczy-jej-siedziba
$[20]$ http://trojmiasto. wyborcza. pl/trojmiasto/1, 153581, 14353626, Sied

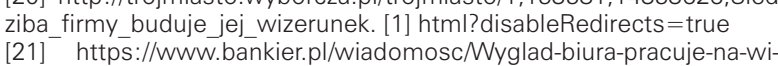
[21] hittps://Mww.bankier.p///iadomosc/Wyglad-biura-pracuje-na-wi-
zerunek-firmy-2040823.html [22] https://businessinsider.com.pl/firmy//strategie//czym-iest-employer-

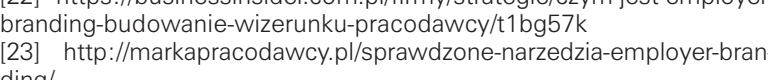

BIBLIOGRAPHY

11] Gehl J., Życie mieddzy budynkami. Uizytkowanie przestrzeni publicz [2] Wines J., Zielona architektura, Taschen/TMC Art. Publishing House,

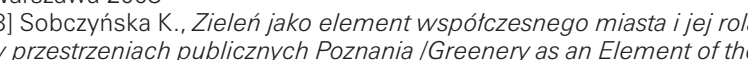
Contemporary City and Its Role in Public Spacess of Poznanhl, Pi.D.D dis Technology, Poznań 2014, source: http://repozyttorium.put.poznan.pl/

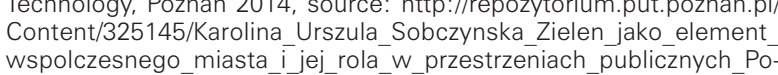
znania.pdf

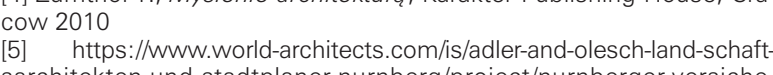

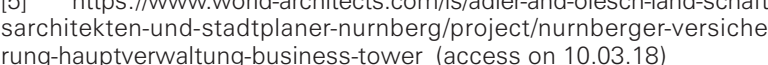

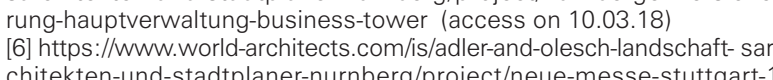
(access on 10.03.18)

architekten wh. World-architects.com/is/adler-and-olesch-landschaftsphinlagune-und-manatihaus (access on 10.03.181 [8] $h$ http://Www.alpha-ic.com
html (access on 10.03.18)

[9] httpe://Www.eisat.de/allgem
-in-nurnberg/ (access on 10.03.

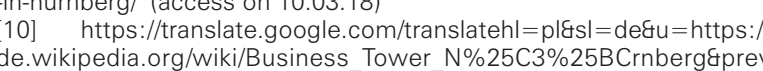
= search (lacess on 10.03.18)
[11] http://fotoffreunde-hip.com/ng/ffh-newsgalerie//Fotowalk\%20Business\%20Tower/newsgalerie.h/mil (access on 10.03.18

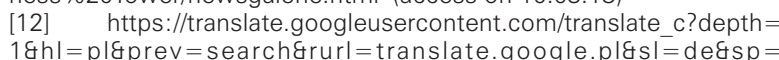

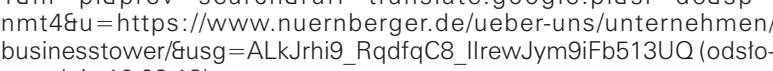
naz dnia 10.03.18

net/structures/business-tower laccess on 10.03.18

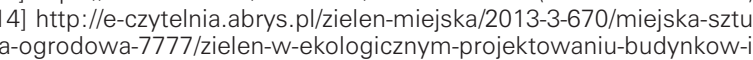

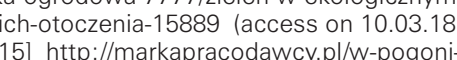

fam-employer-branding/ (access on 5.05.2018)

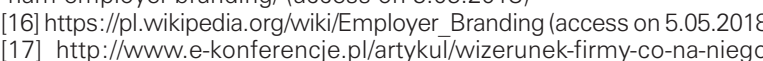
-wplywa/2183/ -firmy/ htps://wizualni.pl/employer-branding-rola-budowaniu-wizerunku-

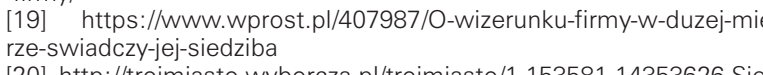
[rze-swiadc/zy-j-j-siedz. ziba_firmy buduje jej wizerunek.html?disableRedirects=true
[21] $^{-}$https://www.bankier.pl/wiadomosc/Wyglad-biura-pracuje-na-wi22erunek-firmy-2040823.html
https://businessinsider.com.pl/firmy/strategie/czym-jest-employ-

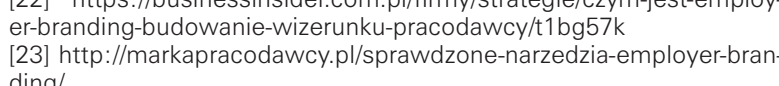

